\title{
Apelin-13 Decreases Epithelial Sodium Channel (ENaC) Expression and Activity in Kidney Collecting Duct Cells
}

\author{
Houda Ayaria Ahmed Chraibia, \\ aDepartment of Pharmacology and Physiology, Faculté de Médecine et des Sciences de la Santé, \\ Université de Sherbrooke, Sherbrooke, QC, Canada, bResearch Center of the Centre Hospitalier \\ Universitaire de Sherbrooke (CR-CHUS), Université de Sherbrooke, Sherbrooke, QC, Canada
}

\author{
Key Words \\ Apelin $\cdot \mathrm{ENaC} \cdot$ Sodium homeostasis $\cdot \mathrm{mpkCCD} \cdot$ Kidney
}

\begin{abstract}
Background/Aims: Apelin and its G protein-coupled receptor APLNR (also known as APJ) are widely expressed within the central nervous system and peripheral organs including heart, lung and kidney. Several studies have shown that the apelin/APJ system is involved in various important physiological processes such as energy metabolism, cardiovascular functions and fluid homeostasis. In the kidney, the apelin/APJ system performs a wide range of activities. We recently demonstrated that apelin antagonises the hydro-osmotic effect of vasopressin on aquaporin-2 water channel (AQP-2) expression by reducing its mRNA and protein levels in collecting duct principal cells. The central role of these cells in water and sodium transport is governed by AQP-2 and the epithelial sodium channel (ENaC). The coordination of these channels is essential for the control of extracellular fluid volume, sodium homeostasis and blood pressure. This study aimed at investigating the role of apelin in the regulation of sodium balance in the distal nephron, and more specifically its involvement in modulating the expression and activity of ENaC in collecting duct principal cells. Methods: mpkCCD cells were incubated in the presence of aldosterone and treated with or without apelin-13. Transepithelial $\mathrm{Na}^{+}$current was measured and the changes in $\mathrm{ENaC}$ expression determined by RT-PCR and immunoblotting. Results: Our data show that apelin-13 reduces the transepithelial sodium amiloride-sensitive current in collecting duct principal cells after $8 \mathrm{~h}$ and $24 \mathrm{~h}$ treatment. This effect was associated with a decrease in $\alpha \mathrm{ENaC}$ subunit expression and mediated through the ERK pathway as well as SGK1 and Nedd4-2. Conclusion: Our findings indicate that apelin is involved in the fine regulation of sodium balance in the renal collecting duct by opposing the effects of aldosterone, likely by activation of $\mathrm{ENaC}$ ubiquitination.
\end{abstract}

(C) 2022 The Author(s). Published by Cell Physiol Biochem Press GmbH\&Co. KG 


\section{Cellular Physiology Cell Physiol Biochem 2022;56:1-12 \\ \begin{tabular}{l|l|l}
\hline DOI: 10.33594/000000488 & ( 2022 The Author(s). Published by
\end{tabular} \\ Published online: 12 January 2022 Cell Physiol Biochem Press GmbH\&Co. KG \\ Ayari et al.: Apelin Decreases ENaC Activity and Expression in mpkCCD Cells}

\section{Introduction}

Apelin is a vasoactive peptide isolated from bovine stomach recognised as the endogenous ligand for a putative receptor related to the angiotensin receptor AT1 (APJ), which belongs to the $G$ protein coupled receptor family $[1,2]$. It originates from a 77-aminoacid precursor, preproapelin, which encompasses several active fragments including apelin-13, -17 , and -36 [3, 4]. Apelin and its receptor are widely expressed in a number of tissues such as central nervous system, heart and blood vessels [5, 6]. In the kidney, the apelin/APJ system is expressed in glomeruli, vascular endothelial cells and all nephron segments including collecting tubules [7-9]. Recent studies show that a second peptide ligand of APJ, elabela, discovered in 2014, is localised in collecting duct principal cells [10-12]. A large body of evidence indicates that the apelin/APJ system plays a crucial role in numerous pathophysiological and physiological processes [13-15]. In the kidney, it is a critical mediator of renal fibrosis, renal ischemia, diabetic nephropathy and hemodialysis [16-18]. In addition, the apelin/APJ system exerts a central role in the regulation of blood pressure, glomerular haemodynamics and acts on the tubule to promote diuresis $[8,19,20]$. Recently, we have determined that the effect on diuresis is due to inhibition of aquaporin-2 (AQP-2) water channel insertion into the apical plasma membrane of the collecting duct cells [21]. The central role of these cells in water and sodium transport is governed by AQP-2 and epithelial sodium channel (ENaC).

$\mathrm{ENaC}$ is a protein complex consisting of three homologous subunits $(\alpha, \beta, \gamma)$ encoded by three different genes [22]. It is expressed at the apical membrane of a variety of tissues, such as the distal nephron of the kidney, the lungs and distal colon [23-25]. This channel is a major regulator of salt and water reabsorption and blood pressure in the aldosteronesensitive distal nephron (ASDN) [26, 27]. Thus, $\mathrm{ENaC}$ is regulated in a very stringent manner, including the involvement of several hormonal factors and mechanisms. For instance, arginine vasopressin and its analogues bind to V2 receptors and increase the activity and translocation of $\mathrm{ENaC}$ to the apical membrane from intracellular stores through activation of protein kinase A [28]. Aldosterone stimulates ENaC activity and expression through different genomic responses $[29,30]$. Aldosterone regulation of $\mathrm{ENaC}$ occurs through receptor-mediated modulation of intracellular signalling pathways involving various kinase cascades, such as inhibition of extracellular signal-regulated kinase (ERK1/2), stimulation of serum and glucocorticoid-regulated kinase (SGK1) or inhibition of the neural precursor cellexpressed developmentally down-regulated protein 4-2 (Nedd4-2), an E3 ubiquitin ligase inducing internalisation and degradation of $\mathrm{ENaC}$ [31-34]. The coordination of ENaC and AQP-2 channels is essential for the control of extracellular fluid volume, sodium homeostasis and blood pressure. The action of the apelin/APJ system on the renal tubule in promoting diuresis is mediated by several signalling pathways, including those involved in the regulation of sodium homeostasis. In light of the above, we aimed to investigate the role of apelin in the regulation of sodium balance in the distal nephron, more specifically its involvement in modulating the expression and activity of ENaC in collecting duct principal cells, as well as elucidate the mechanisms implicated in this regulation.

\section{Materials and Methods}

\section{Cell culture}

Immortalised mouse kidney cortical collecting duct cells (mpkCCDc14) were maintained in DMEM-F12 (Dulbecco's modified Eagle's medium / Ham's F-12 (v/v), Wisent) supplemented with $5 \mu \mathrm{g} / \mathrm{ml}$ transferrin, $20 \mathrm{mM}$ D-glucose, $2 \%$ foetal bovine serum (FBS), $20 \mathrm{mM} \mathrm{HEPES,} 1 \%$ penicillin/streptomycin, $5 \mu \mathrm{g} / \mathrm{ml}$ insulin, $50 \mathrm{nM}$ dexamethasone, $60 \mathrm{nM}$ sodium selenate, $1 \mathrm{nM}$ triiodothyronine, and $10 \mathrm{ng} / \mathrm{ml}$ epidermal growth factor (EGF). Cells were plated in $100 \mathrm{~mm}$ dishes at $37^{\circ} \mathrm{C}$ and $5 \% \mathrm{CO}_{2}, 95 \%$ air atmosphere until $80 \%$ confluency, after which cells were transferred into $4.5 \mathrm{~cm}^{2}$ semi-permeable filter-containing pores measuring $0.4 \mu \mathrm{m}$ (Greiner-Bio-One, Germany) at a density of 80000 cells $/ \mathrm{cm}^{2}$. Upon reaching a transepithelial resistance 


\section{Cellular Physiology Cell Physiol Biochem 2022;56:1-12

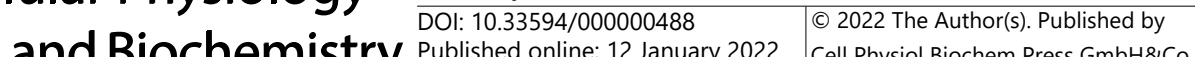 \\ \begin{tabular}{ll} 
Published online: 12 January 2022 Cell Physiol Biochem Press GmbH\&Co. KG \\
\hline A
\end{tabular} \\ Ayari et al.: Apelin Decreases ENaC Activity and Expression in mpkCCD Cells}

of $1200 \Omega . \mathrm{cm}^{2}$ (4-5 days after seeding), cells were pretreated for $8 \mathrm{~h}$ or $24 \mathrm{~h}$ with $1 \mu \mathrm{M}$ aldosterone (SigmaAldrich, USA) to induce endogenous ENaC expression and subsequently treated, in the continued presence of aldosterone, with or without $200 \mathrm{nM}$ apelin-13 for varying time intervals. All treatments were added to the basolateral compartment and culture medium was renewed daily. Apelin-13 was generously provided by P. Sarret, IPS, FMSS, Université de Sherbrooke.

\section{Transepithelial current measurement}

Transepithelial voltage (Vte) and resistance (Rte) of each filter were measured under sterile conditions with an EndOhm-6 coupled to an EVOM2 (WPI, Sarasota, FL, USA) before and after treatment. Briefly, Vte was measured by means of a set of $2 \mathrm{Ag}-\mathrm{AgCl}$ electrodes and determined with the apical electrode as reference. Rte was measured by passage of current through the cell monolayer and measurement of the resulting voltage gradient across the cells. The transepithelial current (Isc) was calculated using Ohm's law. $10 \mu \mathrm{M}$ amiloride was added in the apical compartment to determine the magnitude of ENaC-mediated sodium transport across the cell monolayer.

\section{RNA isolation and QPCR}

Total RNA was isolated using Trizol Reagent (Life Technologies, Burlington, ON, Canada) according to the manufacturer's instructions. To remove potentially contaminating DNA, total RNA was treated with DNase (Promega, Madison, WI) for 1 hour at $37^{\circ} \mathrm{C}$. RNA was reverse-transcribed according to the manufacturer's procedure (Quantitect Qiagen, CA) and cDNA samples were amplified using the specific primers for $\alpha \mathrm{ENaC}$ forward, 5'CGGAGTTGCTAAACTCAACATC3', and reverse, 5'TGGAGACCAGTACCGGCT3', and for GAPDH forward, 5'TGGTGCCAAAAGGGTCATC3', and reverse 5'CTTCGACGATGCCAAAGTTG3'. The resulting cDNAs were used as templates in duplicate qPCR reactions each in triplicate, using a Brilliant II SYBR Green qPCR Master Mix kit (Stratagene, Mississauga, Ontario) in a MX3000P Real-Time PCR system to assess changes in expression of several transcripts. Fold-change values were calculated in "relative change" compared to the control condition, normalised with the expression of mGAPDH, and calculated according to the Pfaffl mathematical model [35].

\section{Western blot analysis}

Total cell lysates were collected in cold lysis buffer (20 mM Tris HCl, pH 7.4, 5 mM EDTA, 40 mM betaglycerophosphate, $30 \mathrm{mM} \mathrm{NaF}$, and 1\% Triton X-100) supplemented with $200 \mu \mathrm{M}$ sodium orthovanadate and complete ${ }^{\mathrm{TM}}$ EDTA-free protease inhibitors (Roche Diagnostics, Laval, QC, Canada). Protein quantification assays were determined using the BCA (bicinchoninic acid) procedure. Lysates were separated on $12 \%$ SDSPAGE gel and transferred onto a PVDF membrane (Polyvinylidene difluoride; Perkin Elmer, Woodbridge, ON). The membrane was blocked in 5\% BSA (Bovine Serum Albumin) in TBS-T (20 mM Tris, $150 \mathrm{mM} \mathrm{NaCl,}$ $0.1 \%$ Tween-20) for $2 \mathrm{~h}$ and then incubated overnight at $4^{\circ} \mathrm{C}$ with the following primary antibodies: anti$\alpha \mathrm{ENaC}$ (rabbit polyclonal, 1/2000, SPC403D, Biosciences Inc, Burlington, ON, Canada); anti-actin (mouse monoclonal, 1/10000, MAB1501, Millipore, CA); anti-p-SGK1 (rabbit monoclonal, ab-55281, 1/1000, Abcam, CA); anti-pNedd4-2 (rabbit polyclonal, 1/1000, ab-73386, Abcam, CA); anti p-ERK (rabbit monoclonal, 1/1000, Cell Signaling 9100, CA); anti-ERK total (rabbit monoclonal, 1/1000, Cell Signaling 9100, CA). Membranes were then incubated with 1/1000 of suitable HRP-conjugated secondary antibody: anti-mouse (NA931V, Santa Cruz, CA); anti-rabbit (NA934V, Amersham, CA) for 2 hours at room temperature. Following the primary and secondary antibody incubations, the blot was washed in TBST three times for at least 10 min. Detection was performed using the Western Lightning Chemiluminescence Reagent Plus kit (Perkin Elmer, Woodbridge, ON, Canada) and revelation carried out using the LICOR system. Densitometric protein analysis was performed using the STUDIO Image software.

\section{Statistical analyses}

Results are expressed as the mean \pm SEM from independent experiments. Each experiment was carried out on cells having the same number of passages and all experiments were performed in quadruple. The number of experiments is indicated in the figure legends. All statistical analyses were performed using Prism 9 software (Graph Pad Software, San Diego, CA). A two-way ANOVA, with the Bonferroni multiple comparison test, were used to analyse the data. Data were considered to be statistically significant at the 95\% confidence level $(\mathrm{p}<0.05)$. 


\section{Cellular Physiology Cell Physiol Biochem 2022;56:1-12 \\ \begin{tabular}{l|l|l} 
DOI: 10.33594/000000488 & (c)22 The Author(s). Published by
\end{tabular} \\ \begin{tabular}{l|l} 
Published online: 12 January 2022 & Cell Physiol Biochem Press GmbH\&Co. KG \\
\hline
\end{tabular} \\ Ayari et al.: Apelin Decreases ENaC Activity and Expression in mpkCCD Cells}

\section{Results}

Apelin-13 reduces amiloride-sensitive sodium current transport in mpkCCD cells

We first investigated whether apelin affects the amiloride-sensitive sodium current. To achieve the latter, electrophysiological measurements of transepithelial sodium current (Isc) were performed in monolayers of mpkCCD cells with high transepithelial resistance $(\geq 1200$ $\Omega . \mathrm{cm}^{2}$ ). The epithelial cell line was then pretreated for $8 \mathrm{~h}$ or $24 \mathrm{~h}$ with $1 \mu \mathrm{M}$ aldosterone to induce endogenous ENaC expression and subsequently treated, in the continued presence of aldosterone, with or without $200 \mathrm{nM}$ apelin-13 for $8 \mathrm{~h}$ or $24 \mathrm{~h}$. Aldosterone treatment produces a significant change in basal sodium Isc of $19 \%$ and $33 \%$ after $8 \mathrm{~h}$ and $24 \mathrm{~h}$ respectively ( $p=0.022$ and 0.010$)$. Basal sodium Isc values were $79.31 \pm 6.29 \mu \mathrm{A}(\mathrm{n}=72)$ in absence of aldosterone, and $94.32 \pm 3.39 \mu \mathrm{A}(\mathrm{n}=60)$ and $105.61 \pm 4.55 \mu \mathrm{A}(\mathrm{n}=60)$ in the presence of aldosterone $8 \mathrm{~h}$ and $24 \mathrm{~h}$, respectively. Amiloride $(10 \mu \mathrm{M})$ was added to the apical membrane at the end of the experiments to confirm that the transepithelial current was mediated by ENaC. In all experimental conditions, amiloride strongly decreased sodium current showing that the majority of basal sodium transport in mpkCCD cells is amiloridesensitive. As illustrated in Fig. 1, treatment with $200 \mathrm{nM}$ apelin-13, in the continued presence of aldosterone, produced a significant decrease in Isc amiloride-sensitive sodium current after $8 \mathrm{~h}$ and $24 \mathrm{~h}(76 \% \pm 12 \%$ and $89 \% \pm 6.3 \%$ respectively, $\mathrm{n}=6)$ compared to aldosterone alone (positive control). A similar decrease was observed when mpkCCD cells were treated with apelin-13 without aldosterone, suggesting that apelin is able to reduce, significantly, the transepithelial sodium current mediated by ENaC channels in the presence or absence of aldosterone (Fig. 1).

\section{Apelin-13 decreases $\alpha$ ENaC mRNA expression}

To assess whether apelin is able to regulate the expression of $\alpha \mathrm{ENaC}$, we first tested the effect of apelin-13 on $\alpha E N a C$ mRNA expression. mpkCCD cells were stimulated with aldosterone to induce endogenous ENaC expression and then treated or not with apelin-13 for $8 \mathrm{~h}$ or $24 \mathrm{~h}$ in the continued presence of ald osterone as described previously. As determined by quantitative RT-PCR (Fig. 2), treatment with aldosterone for $8 \mathrm{~h}$ and $24 \mathrm{~h}$ induced a 4.01 \pm 0.31 and $3.96 \pm 0.92$ fold increase in $\alpha \mathrm{ENaC}$ mRNA compared to untreated cells. These results are consistent with previous findings showing that aldosterone stimulates ENaC transcription [30, 36, 37]. Treatment of mpkCCD cells with apelin-13 for $8 \mathrm{~h}$ and $24 \mathrm{~h}$ in the presence of aldosterone decreased $\alpha E N a C$ mRNA by $61 \%$ and $60 \%(n=4)$, respectively, suggesting that apelin-13 induces a inhibitory effect on $\alpha \mathrm{ENaC}$ transcription in mpkCCD cells.

Fig. 1. Effect of apelin-13 on transepithelial amiloride-sensitive sodium current (Isc) in mpkCCD cells.Cells were treated with aldosterone $(1 \mu \mathrm{M})$ for $8 \mathrm{~h}$ or $24 \mathrm{~h}$ in absence or presence of apelin-13 (200nM). The white bar represents the negative control (without aldosterone or apelin). Values were normalized to means of positive control measurements (pretreatment with aldosterone for $8 \mathrm{~h}$ or $24 \mathrm{~h}$ ) and represent the means \pm SEM of percentages of amiloride-sensitive current in 5 separate experiments. $10 \mu \mathrm{M}$ of amiloride was added to the apical membrane at the end of the experiment to determine the involvement of $\mathrm{ENaC}$ in the Isc current. Each experiment contained 3 to 4 filters per condition. Results were analyzed by two-way ANOVA with a Bonferroni post-hoc multiple comparison test.

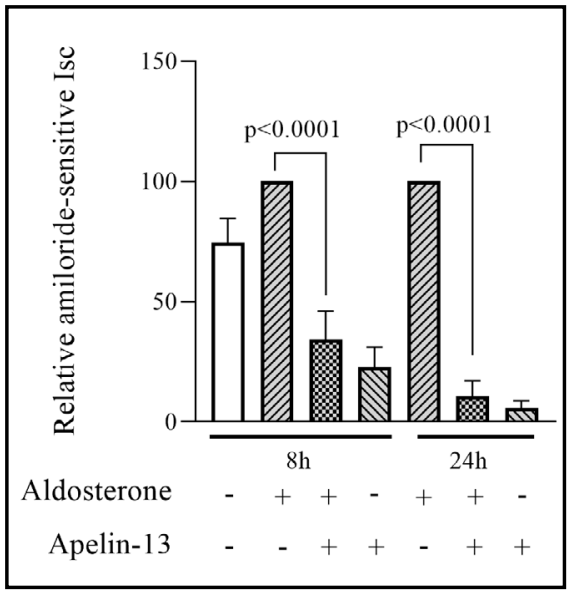


Fig. 2. Effect of apelin-13 on $\alpha E N a C$ mRNA expression. mpkCCD cells were pretreated with $1 \mu \mathrm{M}$ of aldosterone for $8 \mathrm{~h}$ (bars 2, 3, 4, 5, 7, 8 and 9) in order to induce an increase $\alpha \mathrm{ENaC}$ mRNA expression and subsequently treated with $200 \mathrm{nM}$ apelin-13 (bars 4 and 8), or not (bars 3 and 7) in the continued presence of aldosterone $(1 \mu \mathrm{M})$ for $8 \mathrm{~h}$ or $24 \mathrm{~h}$. The bars 5 and 9 represent the mpkCCD cells pretreated with aldosterone and treated with apelin in the absence of aldosterone. The white bars represent the negative control without aldosterone or apelin (- aldosterone, - apelin-13). RNA extraction and reverse transcription were performed as described in experimental procedures. Real-time qPCR was performed us-

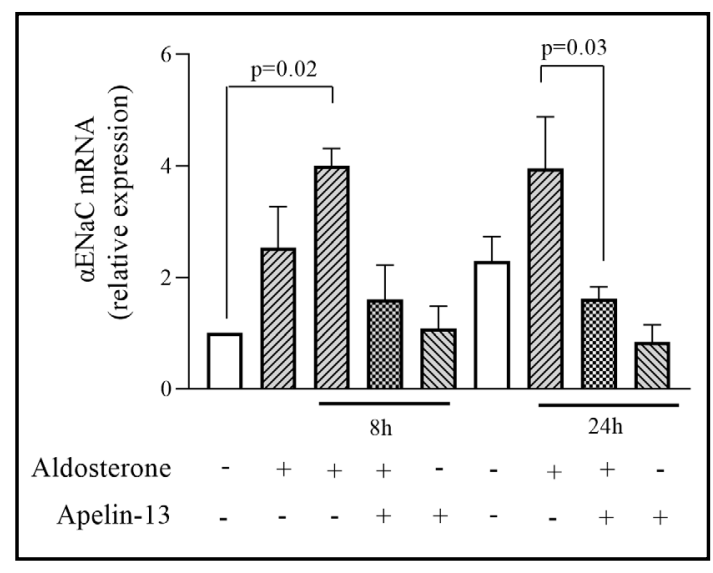
ing specific primers for mouse $\alpha \mathrm{ENaC}$. The relative amounts of $\alpha E N a C$ mRNA were calculated according to the method of Pfaffl [35], compared to the untreated control and normalized on the reference mouse GAPDH gene. Bars represent means \pm SEM from 4 independent experiments, each performed in duplicate. Data were analyzed by two-way ANOVA with a Bonferroni post-hoc multiple comparison test.

\section{Effect of apelin-13 on aldosterone-induced $\alpha E N a C$ protein expression}

We next assessed whether apelin-13 treatment induces a decrease in $\alpha \mathrm{ENaC}$ protein expression. To this end, mpkCCD cells were stimulated with aldosterone and then treated or not with apelin-13 for $8 \mathrm{~h}$ or $24 \mathrm{~h}$ in the continued presence of aldosterone. As shown in Fig. 3, there was no significant change in the expression of ENaC detected at a molecular weight of $95 \mathrm{kDa}$ (as corrected for $\beta$-actin) induced after $8 \mathrm{~h}$ aldosterone treatment compared with unstimulated cells. However, a significant $31 \%$ decrease in the expression of the $\alpha \mathrm{ENaC}$ protein was observed when mpkCCD cells were treated with apelin- 13 for $24 \mathrm{~h}(\mathrm{n}=8)$. This reduction is consistent with the inhibitory effect of apelin on ENaC mRNA expression.

\section{Effect of apelin-13 on pERK1/2 in mpkCCD cells}

Aldosterone is known to regulate the function of ENaC through a variety of mechanisms, including an inhibition of extracellular signal-regulated kinase (ERK), an increase in expression and activation of SGK1 (a serum-and-glucocorticoid-induced kinase) [38] which in turn phosphorylates Nedd4-2, (a ubiquitin ligase) which interacts with ENaC and contributes to enhancing its expression at the plasma membrane [32, 39]. We therefore investigated whether the inhibitory effect of apelin on $\mathrm{ENaC}$ could be mediated by these signalling pathways.

To determine whether the inhibitory effect of apelin on ENaC is mediated by the ERK pathway, mpkCCD cells were treated with apelin-13 for 5, 10, 30 and $60 \mathrm{~min}$ in the presence of aldosterone. ERK total and its phosphorylated form (p-ERK) were detected using specific antibodies as described in the Methods section and assessed by Western blot. As shown in Fig. 4, treatment with apelin-13 induced significant ERK phosphorylation after $30 \mathrm{~min}$ whereas this phosphorylation could not be maintained until $60 \mathrm{~min}(\mathrm{n}=5)$. These results suggest that the ERK pathway is involved in the apelin regulation of $\mathrm{ENaC}$, in accordance with the mechanisms previously described in the action of the apelinergic system in the kidney [40, 41].

\section{Effect of apelin-13 on SGK-1 phosphorylation in mpkCCD cells}

We subsequently investigated whether the SGK pathway is involved in the inhibition of ENaC by apelin. mpkCCD cells were accordingly treated with apelin-13 for 5, 10, 30 and $60 \mathrm{~min}$ in the presence of aldosterone; the non-phosphorylated and phosphorylated forms of SGK-1 were assessed by Western blot. Cells treated with aldosterone alone showed a 
Fig. 3. Effect of apelin-13 on $\alpha E N a C$ protein synthesis. (A) Representative immunoblot showing the expression of $\alpha$-ENaC in the protein extracts from mpkCCD cells after treatment with aldosterone $(1 \mu \mathrm{M})$ in the absence or presence of apelin-13 (200 nM) for $8 \mathrm{~h}$ or $24 \mathrm{~h}$. $\beta$-Actin was used as a loading control. (B) Densitometric analysis of $\alpha$-ENaC expression resulting from 8 independent experiments, expressed as mean \pm SEM analyzed by two-way ANOVA with a Bonferroni post-hoc multiple comparison test.

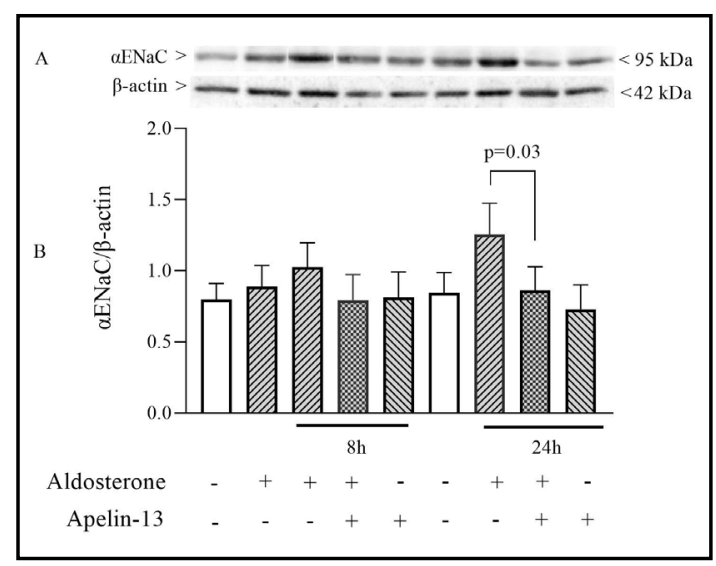

Fig. 4. Effect of apelin-13 on pERK expression. (A) Representative immunoblot showing p-ERK and ERK total expression in protein extracts from mpkCCD cells following treatment with $1 \mu \mathrm{M}$ aldosterone in the absence or presence of apelin-13 (200 nM) for 5, 10, 30, 60 min. Bar 1 represents mpkCCD cells untreated and bar 2 represents a pretreatment by aldosterone for 8h. (B) Densitometric analysis of p-ERK expression resulting from 5 independent experiments, each performed in duplicate. Bars represent means \pm SEM. Data were analyzed by two-way ANOVA with a Bonferroni post-hoc multiple comparison test.

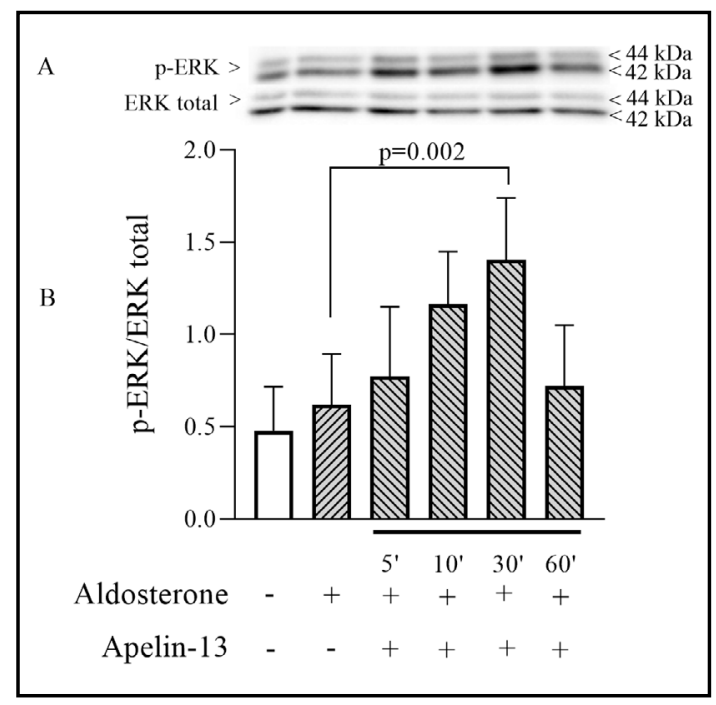

strong increase in p-SGK/SGKtotal ratio (Fig. 5) in accordance with previously described data showing the central role of SGK-1 in the regulation of ENaC by aldosterone $[42,43]$. This large activation of the SGK pathway was significantly reduced when cells were treated with apelin-13 for 5 and 10 min suggesting that the decrease in p-SGK/SGKtotal ratio could be responsible for the reduction in ENaC activity by apelin.

\section{Effect of apelin-13 on Nedd4-2 phosphorylation in mpkCCD cells}

An acknowledged central mechanism by which Sgk1 stimulates ENaC is the phosphorylation of the ubiquitin ligase Nedd4-2 which is thus prevented from ubiquitinating this channel $[32,44]$. In order to verify whether the inhibitory effect of apelin on ENaC is in part due to a decrease in Nedd4-2 phosphorylation, experiments were performed to detect the presence of phosphorylated and non-phosphorylated forms of Nedd4-2 following treatment of mpkCCD cells for 5, 10, 30 and 60 minutes. As illustrated in Fig. 6, apelin-13 treatment in the presence of aldosterone showed a progressive decrease in the phosphorylated form of Nedd4-2 compared to that obtained after treatment with aldosterone alone. The p-Nedd4-2/ Nedd $4-2$ ratio was respectively 1.7 and 0.9 when cells were treated with aldosterone in the absence or presence of apelin-13 for 60 minutes.

These data suggest that the inhibition of ENaC by apelin may be explained, in part, by the stimulation of $\mathrm{ENaC}$ ubiquitination. 


\section{Cellular Physiology Cell Physiol Biochem 2022;56:1-12 and Biochemistry DOl: 10.33594/000000488 202022 The Author(s). Published by \\ Published online: 12 January 2022 Cell Physiol Biochem Press GmbH\&Co. KG \\ Ayari et al.: Apelin Decreases ENaC Activity and Expression in mpkCCD Cells}

Fig. 5. Effect of apelin-13 on SGK1 phosphorylation. (A) Representative immunoblot showing p-SGK1 and SGK1-total expression in protein extracts from mpkCCD cells following treatment with $1 \mu \mathrm{M}$ aldosterone in the absence or presence of apelin-13 (200 nM) for 5, 10, 30 and 60 min. Bar 1 represents mpkCCD cells untreated and bar 2 represents a pretreatment by aldosterone for $8 \mathrm{~h}$. (B) Densitometric analysis of p-SGK1 expression resulting from 4 independent experiments, each performed in duplicate. Bars represent means \pm SEM. Data were analyzed by two-way ANOVA with a Bonferroni post-hoc multiple comparison test.

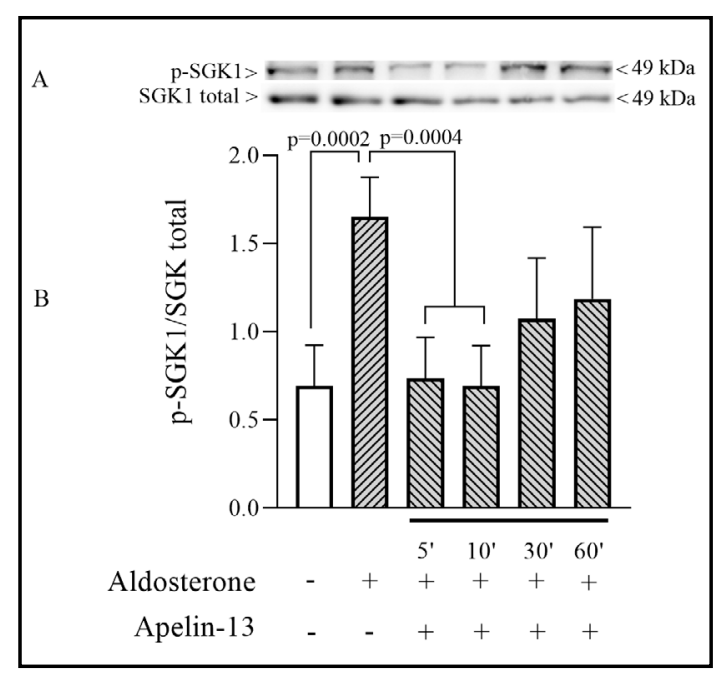

Fig. 6. Effect of apelin-13 on p-Nedd4-2 expression. (A) Representative immunoblot showing expression of pNedd 4-2 and Nedd4-2 total in protein extracts from mpkCCD cells after treatment with $1 \mu \mathrm{M}$ aldosterone in the absence or presence of apelin-13 $(200 \mathrm{nM})$ for 5, 10, 30 and $60 \mathrm{~min}$. Bar 1 represents mpkCCD cells untreated and bar 2 represents a pretreatment by aldosterone for $8 \mathrm{~h}$. (B) Densitometric analysis of the expression of pNedd4-2 resulting from 4 independent experiments, each performed in duplicate. Bars represent means \pm SEM. Data were analyzed by two-way ANOVA with a Bonferroni posthoc multiple comparison test.

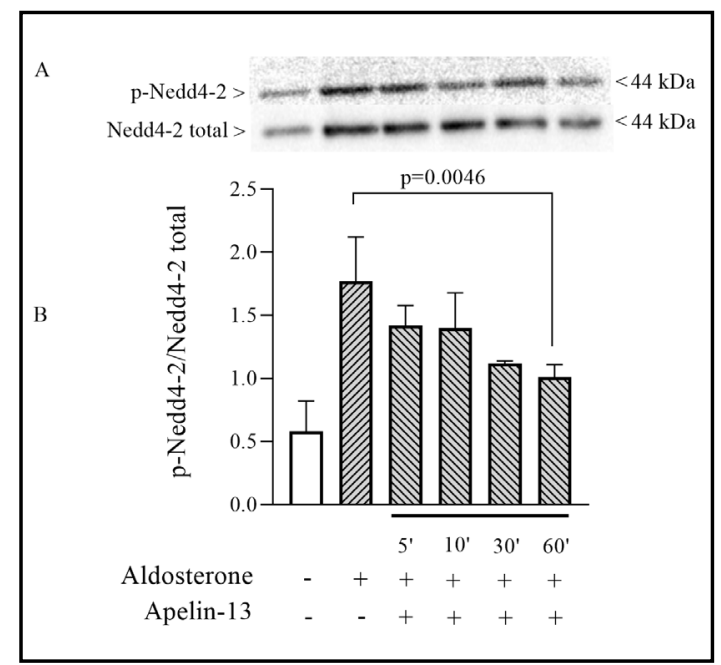

\section{Discussion}

The apelinergic system is expressed in a wide variety of tissues including the brain, heart and kidneys. Its involvement in several physiological functions including energy metabolism, cardiac contractility and fluid homeostasis has been widely studied over the past decade. Several studies have reported key findings regarding the role of the apelinergic system in disorders of water and sodium balance and its interaction between vasopressin and the renin-angiotensin-aldosterone system (RAAS) [45-49]. We, and others, have recently demonstrated that apelin inhibits vasopressin-induced translocation of aquaporin 2 (AQP2) channels to the apical membrane of collecting duct principal cells and therefore prevents water reabsorption $[20,21]$. The function of AQP-2 is tightly coordinated with that of ENaC, a channel which constitutes the rate-limiting step for transepithelial sodium transport in this section of the nephron. In this setting, we hypothesised that apelin-13 could also play an important role in the downregulation of $\mathrm{ENaC}$ function and expression. Our current results provide evidence that aldosterone prompts an increase in amiloride-sensitive sodium current in a collecting duct cell line, thus supporting previously-described findings [50, 51]. This activation was significantly reduced by apelin-13 (Fig. 1). 
In addition, our data show that the application of apelin-13 on mpkCCD cells, in the continuous presence of aldosterone, reduced the expression of the $\alpha \mathrm{ENaC}$ subunit (Fig. 2 and 3). Diverse mechanisms, including variation in channel synthesis, regulation of intracellular channel trafficking, membrane insertion and post-translational modifications that alter channel-open probability (Po) or increase their endocytosis are crucial in controlling channel function [52]. These mechanisms are not mutually exclusive and their combination can be employed to achieve sodium transport mediated by ENaC according to the equation: $I_{N a}=g_{N a} \cdot N \cdot P o \cdot\left(E-E_{N a}\right)$. Thus, we believe that the differences observed on the current measurements and channel expression do not reflect any discrepancy. The vectorial movement of sodium establishes an osmotic gradient that facilitates the movement of water in the same direction while the inhibition of $\mathrm{ENaC}$ is associated with an imbalance of sodium and water [53]. Thus, our findings are consistent with recent data showing that the apelinergic system reduces water reabsorption $[20,21]$.

In addition to the above, we also endeavoured to determine the mechanisms by which apelin modulates the amiloride-sensitive sodium current. ERK, SGK1 and Nedd4-2 appear to be among the promising pathways for investigation. Indeed, several studies have demonstrated that ERK is a crucial factor in the regulation of ENaC activity, trafficking and transcription. Whereas the long-term effect of ERK is thought to involve an inhibition of ENaC transcription [54], the short-term inhibition is likely to be mediated by phosphorylation of ENaC subunits [34].

Numerous evidence supports an inhibitory effect on $\mathrm{ENaC}$, whether tonic or in response to epidermal growth factor (EGF) [34, 55, 56]. A study by the Marunaka group showed that a major effect of hypotonic stress on transcriptional regulation of $\mathrm{ENaC}$ is caused by ERK inactivation (dephosphorylation) and that this dephosphorylation is mediated through the p38-dependent induction of MKP-1 [57]. Furthermore, aldosterone stimulates sodium transport in part by increasing GILZ1 expression, which inhibits ERK signalling, and hence acts in concert with SGK1 to enhance ENaC-mediated sodium current [56]. On the other hand, several studies show that the ERK1/2 signaling pathway is activated by apelin treatment in a time-dependent manner [58-62]. Indeed, Wang et al. shown that the treatment of LX2-cells with apelin-13 displayed an increased ERK1/2 phosphorylation within 45 minutes and this effect persisted up to $1 \mathrm{~h}$ [61]. However, using HEK293 cells, Sun and colleagues shown that a considerable increase in ERK1/2 phosphorylation is obtained after 2 and 5 minutes of apelin treatment and that this phosphorylation is reduced to control values after 10 minutes of treatment [62]. Similar effect was found by Bai and colleagues, but the peak level of ERK1/2 phosphorylation was at 10 minutes of apelin treatment following by a decrease to control values at 20 and 30 minutes [58]. In our study, treatment of mpkCCD cells with apelin-13 induced significant ERK1/2 phosphorylation after 30 min whereas the phosphorylation return to control values after $60 \mathrm{~min}$ of apelin treatment. The dissimilarity of response of apelin on ERK1/2 phosphorylation could be attributed, in part, to the cells used in these different studies.

On the other hand, aldosterone also acts through the mineralocorticoid receptor (MR) to rapidly increase SGK1 gene transcription and, thus, SGK1 protein levels [63]. Importantly, this kinase must also be activated by two phosphorylation events that control its inherent activity [64]. Activated SGK1 in turn phosphorylates and regulates various targets, most notably the ubiquitin ligase Nedd4-2 [32]. Thus, SGK phosphorylates ENaC and inhibits its internalisation from the plasma membrane and subsequent degradation, this double negative (inhibiting the inhibitor) thus resulting in $\mathrm{ENaC}$ accumulation at the apical plasma membrane $[23,65]$. Our results support these aforementioned studies and provide further evidence that aldosterone activates a phosphorylation of SGK and Nedd4-2. We also show that this phosphorylation was considerably reduced following the application of apelin-13 to mpkCCD cells. The above findings suggest that apelin may represent an important activator of ENaC ubiquitination which may explain the decrease in sodium amiloride sensitive current. 


\section{Cellular Physiology Cell Physiol Biochem 2022;56:1-12 \begin{tabular}{l|l|l}
\cline { 3 - 3 } DOI: 10.33594/000000488 & (c) 22 The Author(s). Published by
\end{tabular} \\ \begin{tabular}{lll} 
Published online: 12 January 2022 & Cell Physiol Biochem Press GmbH\&Co. KG \\
\hline
\end{tabular} \\ Ayari et al.: Apelin Decreases ENaC Activity and Expression in mpkCCD Cells}

\section{Conclusion}

The present experiments show that apelin decreases the amiloride-sensitive sodium current. This decrease is associated with modulation of the ERK, SGK and Nedd4-2 pathways, suggesting the activation of ENaC ubiquitination. Further studies are needed to confirm this hypothesis. These results corroborate our recently published data showing that apelin induces downregulation of AQP2 in mpkCCD cells and provide further evidence that the apelinergic system is directly involved in the regulation of sodium and water balance in the distal nephron of the kidney.

\section{Acknowledgements}

\section{Author Contributions}

HA and AC conceived the study and experiments, performed and analysed the data. HA contributed to the writing of the manuscript. AC wrote the paper and supervised the project.

\section{Funding}

This work was supported by the CR-CHUS, the FMSS and by the Canada Foundation for Innovation (CFI), Kidney Foundation of Canada grants (KFOC) and Natural Sciences and Engineering Research Council of Canada (NSERC) grants to Ahmed Chraibi.

\section{Disclosure Statement}

The authors declare that they have no conflicts of interest.

\section{References}

1 O’Dowd BF, Heiber M, Chan A, Heng HH, Tsui LC, Kennedy JL, Shi X, Petronis A, George SR, Nguyen T: A human gene that shows identity with the gene encoding the angiotensin receptor is located on chromosome 11. Gene 1993;136:355-360.

2 Tatemoto K, Hosoya M, Habata Y, Fujii R, Kakegawa T, Zou MX, Kawamata Y, Fukusumi S, Hinuma S, Kitada C, Kurokawa T, Onda H, Fujino M: Isolation and characterization of a novel endogenous peptide ligand for the human APJ receptor. Biochem Biophys Res Commun 1998;251:471-476.

3 Hosoya M, Kawamata Y, Fukusumi S, Fujii R, Habata Y, Hinuma S, Kitada C, Honda S, Kurokawa T, Onda H, Nishimura 0, Fujino M: Molecular and functional characteristics of APJ. Tissue distribution of mRNA and interaction with the endogenous ligand apelin. J Biol Chem 2000;275:21061-21067.

4 Lee DK, Cheng R, Nguyen T, Fan T, Kariyawasam AP, Liu Y, Osmond DH, George SR, BF OD: Characterization of apelin, the ligand for the APJ receptor. J Neurochem 2000;74:34-41.

5 Kawamata Y, Habata Y, Fukusumi S, Hosoya M, Fujii R, Hinuma S, Nishizawa N, Kitada C, Onda H, Nishimura O, Fujino M: Molecular properties of apelin: tissue distribution and receptor binding. Biochim Biophys Acta 2001;1538:162-171.

6 O'Carroll AM, Selby TL, Palkovits M, SJ. L: Distribution of mRNA encoding B78/apj, the rat homologue of the human APJ receptor, and its endogenous ligand apelin in brain and peripheral tissues. Biochim Biophys Acta 2000;1492:72-80.

7 De Falco M, De Luca L, Onori N, Cavallotti I, Artigiano F, Esposito V, De Luca B, Laforgia V, Groeger AM, De Luca A: Apelin expression in normal human tissues. In vivo 2002;16:333-336.

8 Hus-Citharel A, Bouby N, Frugiere A, Bodineau L, Gasc JM, Llorens-Cortes C: Effect of apelin on glomerular hemodynamic function in the rat kidney. Kidney Int 2008;74:486-494.

9 O'Carroll AM, Salih S, Griffiths PR, Bijabhai A, Knepper MA, Lolait SJ: Expression and functional implications of the renal apelinergic system in rodents. PLoS One 2017;12:e0183094. 


\section{Cellular Physiology Cell Physiol Biochem 2022;56:1-12 \begin{tabular}{ll|l} 
and Bioch $10.33594 / 000000488$ & (c)22 The Author(s). Published by
\end{tabular} and BIOChemistry Published online: 12 January 2022 Cell Physiol Biochem Press GmbH\&Co. KG \\ Ayari et al.: Apelin Decreases ENaC Activity and Expression in mpkCCD Cells}

10 Chen H, Wan D, Wang L, Peng A, Xiao H, Petersen RB, Liu C, Zheng L, Huang K: Apelin protects against acute renal injury by inhibiting TGF-beta1. Biochim Biophys Acta 2015;1852:1278-1287.

11 Chen H, Wang L, Wang W, Cheng C, Zhang Y, Wang C, Miao X, Wang J, Li J, Zheng L, Huang K: ELABELA and an ELABELA fragment protect against AKI. J Am Soc Nephrol 2017;28:2694-2707.

12 Xu C, Wang F, Chen Y, Xie S, Sng D, Reversade B, Yang T: ELABELA antagonizes intrarenal reninangiotensin system to lower blood pressure and protects against renal injury. Am J Physiol Renal Physiol 2020;318:F1122-F1135.

13 Reaux A, De Mota N, Skultetyova I, Lenkei Z, El Messari S, Gallatz K, Corvol P, Palkovits M, Llorens-Cortès C: Physiological role of a novel neuropeptide, apelin, and its receptor in the rat brain. J Neurochem 2001;77.:1085-1096.

14 Szokodi I, Tavi P, Foldes G, Voutilainen-Myllyla S, Ilves M, Tokola H, Pikkarainen S, Piuhola J, Rysa J, Toth M, Ruskoaho H: Apelin, the novel endogenous ligand of the orphan receptor APJ, regulates cardiac contractility. Circ Res 2002;91:434-440.

15 Tatemoto K, Takayama K, Zou M, Kumaki I, Zhang W, Kumano K, Fujimiya M: The novel peptide apelin lowers blood pressure via a nitric oxide-dependent mechanism. Regul Pept 2001;99:87-92.

16 Guo C, Liu Y, Zhao W, Wei S, Zhang X, Wang W, Zeng X: Apelin promotes diabetic nephropathy by inducing podocyte dysfunction via inhibiting proteasome activities. J Cell Mol Med 2015;19:2273-2285.

17 Mafra D, Lobo JC, Farage NE, Stockler-Pinto MB, Leal VO, Calixto A, Geloneze B: The relationship between apelin and parathyroid hormone in hemodialysis patients. Ren Fail 2012;34:970-973.

18 Nishida M, Okumura Y, Oka T, Toiyama K, Ozawa S, Itoi T, Hamaoka K: The role of apelin on the alleviative effect of Angiotensin receptor blocker in unilateral ureteral obstruction-induced renal fibrosis. Nephron Extra 2012;2:39-47.

19 De Mota N, Reaux-Le Goazigo A, El Messari S, Chartrel N, Roesch D, Dujardin C, Kordon C, Vaudry H, Moos F, Llorens-Cortes C: Apelin, a potent diuretic neuropeptide counteracting vasopressin actions through inhibition of vasopressin neuron activity and vasopressin release. Proc Natl Acad Sci U S A 2004;101:10464-10469.

20 Hus-Citharel A, Bodineau L, Frugiere A, Joubert F, Bouby N, Llorens-Cortes C: Apelin Counteracts Vasopressin-Induced Water Reabsorption via Cross Talk Between Apelin and Vasopressin Receptor Signaling Pathways in the Rat Collecting Duct. Endocrinology 2014;155:4483-4493.

21 Boulkeroua C, Ayari H, Khalfaoui T, Lafrance M, Besserer-Offroy E, Ekindi N, Sabbagh R, Dumaine R, Lesur O, Sarret P, Chraibi A: Apelin-13 Regulates Vasopressin-Induced Aquaporin-2 Expression and Trafficking in Kidney Collecting Duct Cells. Cell Physiol Biochem 2019;53:687-700.

22 Canessa CM, Schild L, Buell G, Thorens B, Gautschi I, Horisberger JD, Rossier BC: Amiloride-sensitive epithelial $\mathrm{Na}+$ channel is made of three homologous subunits. Nature 1994;367:463-467.

23 Bhalla V, Hallows KR: Mechanisms of ENaC Regulation and Clinical Implications. J Am Soc Nephrol 2008;19 1845-1854.

24 Duc C, Farman N, Canessa CM, Bonvalet JP, Rossier BC: Cell-specific expression of epithelial sodium channel alpha, beta, and gamma subunits in aldosterone-responsive epithelia from the rat: localization by in situ hybridization and immunocytochemistry. J Cell Biol 1994;127:1907-1921.

25 Kunzelmann K, Mall M: Electrolyte transport in the mammalian colon: mechanisms and implications for disease. Physiol Rev 2002;82:245-289.

26 Kleyman TR, Kashlan OB, Hughey RP: Epithelial Na(+) Channel Regulation by Extracellular and Intracellular Factors. Annu Rev Physiol 2018;80:263-281.

27 Frindt G, Yang L, Bamberg K, Palmer LG: Na restriction activates epithelial Na channels in rat kidney through two mechanisms and decreases distal $\mathrm{Na}(+)$ delivery. J Physiol 2018;596:3585-3602.

28 Ecelbarger CA, Kim GH, Wade JB, Knepper MA: Regulation of the abundance of renal sodium transporters and channels by vasopressin. Exp Neurol 2001;171:227-234.

29 Frindt G, Palmer LG: Surface expression of sodium channels and transporters in rat kidney: effects of dietary sodium. Am J Physiol Renal Physiol 2009;297:F1249-1255.

30 Verrey F: Early aldosterone effects. Exp Nephrol 1998;6:294-301.

31 Chen SY, Bhargava A, Mastroberardino L, Meijer OC, Wang J, Buse P, Firestone GL, Verrey F, Pearce D: Epithelial sodium channel regulated by aldosterone-induced protein sgk. Proc Natl Acad Sci U S A 1999;96:2514-2519. 


\section{Cellular Physiology Cell Physiol Biochem 2022;56:1-12 \begin{tabular}{l|l|l}
\cline { 2 - 2 } DOl: $10.33594 / 000000488$ & (c) 2022 The Author(s). Published by
\end{tabular} and BIOChemistry Published online: 12 January 2022 Cell Physiol Biochem Press GmbH\&Co. KG \\ Ayari et al.: Apelin Decreases ENaC Activity and Expression in mpkCCD Cells}

32 Debonneville C, Flores SY, Kamynina E, Plant PJ, Tauxe C, Thomas MA, Munster C, Chraibi A, Pratt JH, Horisberger JD, Pearce D, Loffing J, Staub O: Phosphorylation of Nedd4-2 by Sgk1 regulates epithelial Na(+) channel cell surface expression. Embo J 2001;20:7052-7059.

33 Ishigami T, Kino T, Minegishi S, Araki N, Umemura M, Ushio H, Saigoh S, Sugiyama M: Regulators of Epithelial Sodium Channels in Aldosterone-Sensitive Distal Nephrons (ASDN): Critical Roles of Nedd4L/ Nedd4-2 and Salt-Sensitive Hypertension. Int J Mol Sci 2020;21:3871.

34 Shi H, Asher C, Chigaev A, Yung Y, Reuveny E, Seger R, Garty H: Interactions of beta and gamma ENaC with Nedd4 can be facilitated by an ERK-mediated phosphorylation. J Biol Chem 2002;277:13539-13547.

35 Pfaffl MW: A new mathematical model for relative quantification in real-time RT-PCR. Nucleic Acids Res 2001;29:e45.

36 Chen L, Zhang X, Zhang W: Regulation of alphaENaC transcription. Vitam Horm 2015;98:101-135.

37 Pearce D, Bhargava A, Cole TJ: Aldosterone: its receptor, target genes, and actions. Vitam Horm 2003;66:2976.

38 Lang F, Pearce D: Regulation of the epithelial Na+ channel by the mTORC2/SGK1 pathway. Nephrol Dial Transplant 2016;31:200-205.

39 Pearce D, Soundararajan R, Trimpert C, Kashlan OB, Deen PM, Kohan DE: Collecting duct principal cell transport processes and their regulation. Clin J Am Soc Nephrol 2015;10:135-146.

40 Chapman FA, Nyimanu D, Maguire JJ, Davenport AP, Newby DE, Dhaun N: The therapeutic potential of apelin in kidney disease. Nat Rev Nephrol 2021;17:840-853.

41 Janssens P, Decuypere JP, Bammens B, Llorens-Cortes C, Vennekens R, Mekahli D: The emerging role of the apelinergic system in kidney physiology and disease. Nephrol Dial Transplant 2021; DOI: 10.1093/ndt/ gfab070.

42 Vallon V LF: New insights into the role of serum- and glucocorticoid-inducible kinase SGK1 in the regulation of renal function and blood pressure. Curr Opin Nephrol Hypertens 2005;14:59-66.

43 Náray-Fejes-Tóth A, Fejes-Tóth G: The sgk, an aldosterone-induced gene in mineralocorticoid target cells, regulates the epithelial sodium channel. Kidney Int 2000;57:1290-1294.

44 Flores SY, Loffing-Cueni D, Kamynina E, Daidie D, Gerbex C, Chabanel S, Dudler J, Loffing J, Staub O: Aldosterone-induced serum and glucocorticoid-induced kinase 1 expression is accompanied by Nedd42 phosphorylation and increased $\mathrm{Na}+$ transport in cortical collecting duct cells. J Am Soc Nephrol 2005;16:2279-2287.

45 Blanchard A, Steichen O, De Mota N, Curis E, Gauci C, Frank M, Wuerzner G, Kamenicky P, Passeron A, Azizi M, Llorens-Cortes C: An abnormal apelin/vasopressin balance may contribute to water retention in patients with the syndrome of inappropriate antidiuretic hormone (SIADH) and heart failure. J Clin Endocrinol Metab 2013;98:2084-2089.

46 Galanth C, Hus-Citharel A, Li B, Llorens-Cortes C: Apelin in the control of body fluid homeostasis and cardiovascular functions. Curr Pharm Des 2012;18:789-798.

47 Sainsily X, Coquerel D, Giguere H, Dumont L, Tran K, Noll C, Ionescu AL, Cote J, Longpre JM, Carpentier A, Marsault E, Lesur O, Sarret P, Auger-Messier M: Elabela Protects Spontaneously Hypertensive Rats From Hypertension and Cardiorenal Dysfunctions Exacerbated by Dietary High-Salt Intake. Front Pharmacol 2021;12:709467.

48 Urwyler SA, Timper K, Fenske W, de Mota N, Blanchard A, Kuhn F, Frech N, Arici B, Rutishauser J, Kopp P, Stettler C, Muller B, Katan M, Llorens-Cortes C, Christ-Crain M: Plasma Apelin Concentrations in Patients With Polyuria-Polydipsia Syndrome. J Clin Endocrinol Metab 2016;101:1917-1923.

49 Wang J, Li N, Gao F, Song R, Zhu S, Geng Z: Balance between angiotensin converting enzyme and angiotensin converting enzyme 2 in patients with chronic heart failure. J Renin Angiotensin Aldosterone Syst 2015;16:553-558.

50 Alvarez de la Rosa D, Li H, Canessa CM: Effects of aldosterone on biosynthesis, traffic, and functional expression of epithelial sodium channels in A6 cells. J Gen Physiol 2002;119:427-442.

51 Niisato N, Taruno A, Marunaka Y: Aldosterone-induced modification of osmoregulated ENaC trafficking. Biochem Biophys Res Commun 2007;361:162-168.

52 Rossier BC, Pradervand S, Schild L, Hummler E: Epithelial sodium channel and the control of sodium balance: interaction between genetic and environmental factors. Annu Rev Physiol 2002;64:877-897.

53 Bankir L, Fernandes S, Bardoux P, Bouby N, Bichet DG: Vasopressin-V2 receptor stimulation reduces sodium excretion in healthy humans. J Am Soc Nephrol 2005;16:1920-1928. 


\section{Cellular Physiology Cell Physiol Biochem 2022;56:1-12 \begin{tabular}{ll|l|l|l}
\hline DOI: 10.33594/000000488 & (C) 2022 The Author(s). Published by \\
\hline
\end{tabular} \\ \begin{tabular}{ll} 
Published online: 12 January 2022 Cell Physiol Biochem Press GmbH\&Co. KG \\
\hline
\end{tabular} \\ Ayari et al.: Apelin Decreases ENaC Activity and Expression in mpkCCD Cells}

54 Shen JP, Cotton CU: Epidermal growth factor inhibits amiloride-sensitive sodium absorption in renal collecting duct cells. Am J Physiol Renal Physiol 2003;284:F57-64.

55 Grossmann C, Freudinger R, Mildenberger S, Krug AW, Gekle M: Evidence for epidermal growth factor receptor as negative-feedback control in aldosterone-induced Na+ reabsorption. Am J Physiol Renal Physiol 2004;286:F1226-1231.

56 Soundararajan R, Zhang T, Wang J, Vandewalle A, Pearce D: A novel role for glucocorticoid-induced leucine zipper protein in epithelial sodium channel-mediated sodium transport. J Biol Chem 2005;280:3997039981.

57 Niisato N, Ohta M, Eaton DC, Marunaka Y: Hypotonic stress upregulates beta- and gamma-ENaC expression through suppression of ERK by inducing MKP-1. Am J Physiol Renal Physiol 2012;303:F240-252.

58 Bai B, Cai X, Jiang Y, Karteris E, Chen J: Heterodimerization of apelin receptor and neurotensin receptor 1 induces phosphorylation of ERK(1/2) and cell proliferation via Galphaq-mediated mechanism. J Cell Mol Med 2014;18:2071-2081.

59 Li Y, Bai YJ, Jiang YR: Apelin induces the proliferation, migration and expression of cytoskeleton and tight junction proteins in human RPE cells via PI-3K/Akt and MAPK/Erk signaling pathways. Int J Clin Exp Pathol 2017;10:10711-10729.

60 Li Y, Bai YJ, Jiang YR, Yu WZ, Shi X, Chen L, Feng J, Sun GB: Apelin-13 Is an Early Promoter of Cytoskeleton and Tight Junction in Diabetic Macular Edema via PI-3K/Akt and MAPK/Erk Signaling Pathways. Biomed Res Int 2018;2018:3242574.

61 Wang Y, Song J, Bian H, Bo J, Lv S, Pan W, Lv X: Apelin promotes hepatic fibrosis through ERK signaling in LX-2 cells. Mol Cell Biochem 2019;460:205-215.

62 Sun X, Iida S, Yoshikawa A, Senbonmatsu R, Imanaka K, Maruyama K, Nishimura S, Inagami T, Senbonmatsu T: Non-activated APJ suppresses the angiotensin II type 1 receptor, whereas apelin-activated APJ acts conversely. Hypertens Res 2011;34:701-706.

63 Soundararajan R, Pearce D, Hughey RP, Kleyman TR: Role of epithelial sodium channels and their regulators in hypertension. J Biol Chem 2010;285:30363-30369.

64 Lu M, Wang J, Jones KT, Ives HE, Feldman ME, Yao LJ, Shokat KM, Ashrafi K, Pearce D: mTOR complex-2 activates ENaC by phosphorylating SGK1. J Am Soc Nephrol 2010;21:811-818.

65 Kabra R, Knight KK, Zhou R, Snyder PM: Nedd4-2 induces endocytosis and degradation of proteolytically cleaved epithelial Na+ channels. J Biol Chem 2008;283:6033-6039. 